\title{
FLORAL REMAINS FROM THE HIGHEST VALDEÓN FORMATION, A MARINE STEPHANIAN UNIT SOUTH OF THE PICOS DE EUROPA, AND COMPARISONS WITH EASTERN ASTURIAS, NW SPAIN
}

\author{
Robert H. WAGNER' and Enrique MARTÍNEZ-GARCÍA \\ 'Jardín Botánico de Córdobal. Avenida de Linneo, s/n. 140()4 Córdoba (Spain). \\ ? Universidad de Oviedo. Departamento de Geología, c/Jesús Arias de Velasco. s/n. 330(0)5 \\ Oviedo (Spain).
}

Wagner, R.H. and Martínez-García, E. 1998. Floral remains from the highest Valdeón Formation, a marine Stephanian unit south of the Picos de Europa, and comparisons with eastern Asturias, NW Spain. Revista Española de Paleontología, 13 (1), 93-106. ISSN (0213-6937.

\begin{abstract}
A critical analysis is presented of the available data on the Valdeón Formation, a Stephanian unit southwest of the Picos de Europa, in northern León. It lies unconformably on Devonian and lower Carboniferous (Mississippian) strata of the Gildar-Montó nappe structure, and is overthrust from the northwest by a variety of older strata of the Ponga unit. The Valdeón Formation, consisting of mudstones, sandstones and lensing conglomerate bands, is largely unfossiliferous and probably marine up to the highest levels where possibly lagoonal deposits contain a drifted megafloral assemblage, which is of Barruelian or later age. This flora is documented here with illustrations and the various taxa are discussed. Comparison is made with a succession of upper Cantabrian and lower Barruelian strata in northern Palencia (Brainosera and Barruelo formations), which show a broadly similar stratigraphic development. Floras from a small terrestrial interval near the base of the predominantly marine strata of Stephanian B age in eastern Asturias (at Fontecha and Arenas de Cabrales) are discussed for the overall comparison, but these floras are later in age and the relevant strata, belonging to the post-Asturian basin, show a different development. These later Stephanian floras are listed but only two species are illustrated.
\end{abstract}

Keywords: Megaflora, Stephanian, stratigraphy, palaeogeography, Cantabrian Mountains, León, Asturias.

\section{RESUMEN}

Se presenta un análisis crítico de la información existente sobre la Formación Valdeón, una unidad estefaniense inmediatamente al suroeste de los Picos de Europa, en el norte de León. Reposa con discordancia angular sobre el Devónico y Misisípico del Manto de Gildar-Montó, y está cabalgada desde el noroeste por la unidad tectónica del Ponga. Consiste en más de $2.0(0) \mathrm{m}$ de lutitas, areniscas y conglomerados lenticulares, probablemente marinos aunque carentes de fósiles hasta llegar a la parte más alta, donde depósitos someros (¿de lagoon?) contienen los restos hotados de una flora continental que se documenta en este trabajo. Presenta una asociación de edad estefaniense, correspondiente al Barrueliense o pisos más altos. El desarrollo estratigrálico de la Formación Valdeón permite una comparación con las formaciones Brañosera y Barruelo de la cuenca postleónica del norte de Palencia. La flora de Valdeón sería, pues, del Barrueliense inferior. Una comparación con las floras de la parte baja de la sucesión post-Astúrica en Asturias oriental (localidades: Sierra de Fontecha y Arenas de Cabrales), de una edad estefaniense mucho más moderna (Estefaniense B sensu St. Etienne) es lícita en cuanto a los registros paleobotánicos, pero choca con un desarrollo estratigráfico muy diferente. Las floras de Fontecha y Arenas se mencionan como listas de especies, con solamente dos ilustraciones de especies importantes.

Palabras clave: Megaflora, Estefaniense, estratigrafía, paleogeografía, Cordillera Cantábrica, León, Asturias. 


\section{THE VALDEÓN BEDS AS A LITHOSTRATIGRAPHIC UNIT}

The Valdeón Formation was introduced by Kutterink (1966) in an unpublished degree thesis, and mentioned subsequently by Boschma (1968) and Boschma \& Van Staalduinen (1968) as part of the Carboniferous strata mapped on the southern flank of the Cantabrian Mountains. It occurs in a synclinal structure in northeastern León, immediately southwest of the

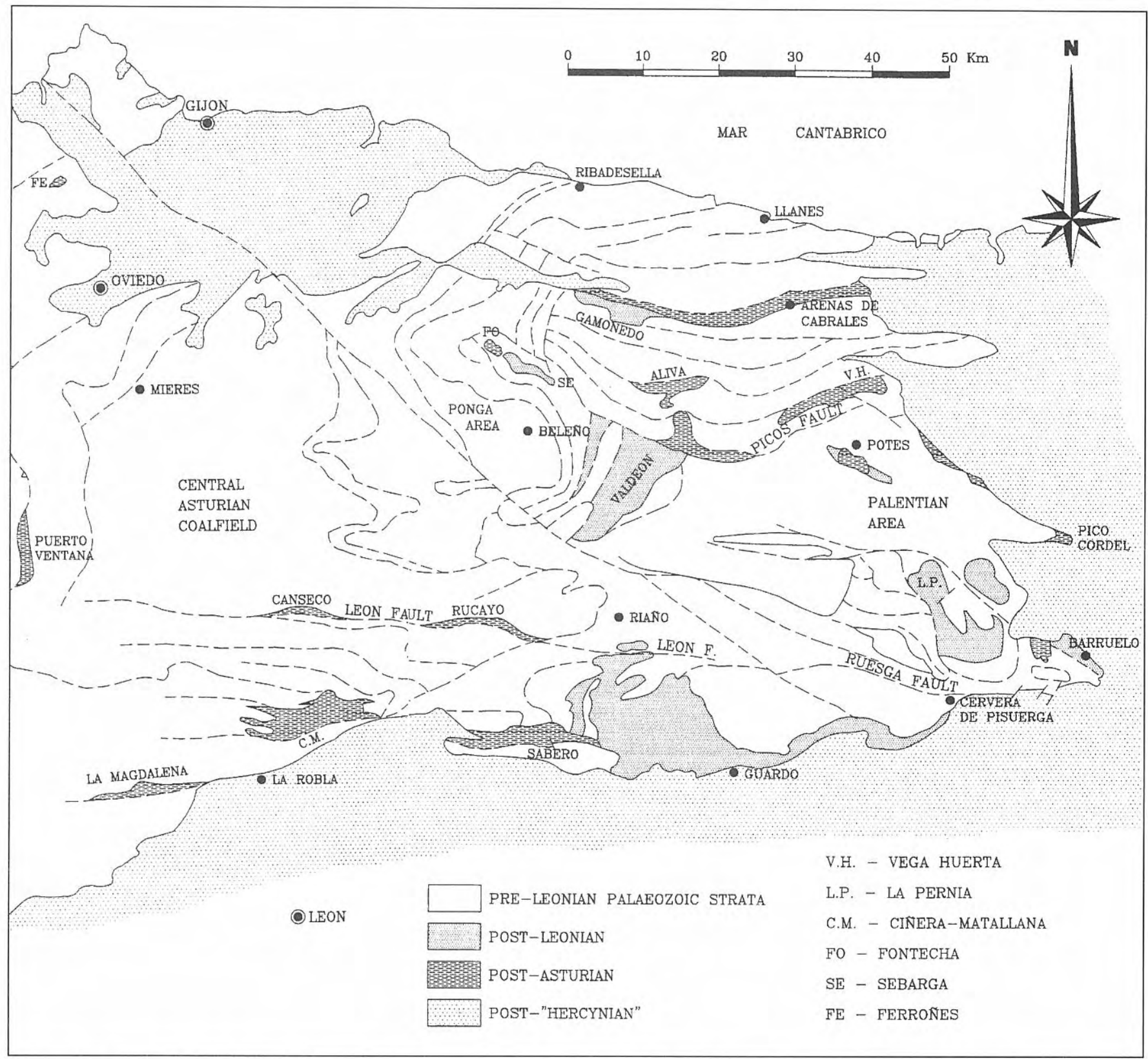

Figure 1. General map showing the outcrop areas of the post-Leonian and post-Asturian successions (upper Westphalian D/Cantabrian/lower Barruelian, and upper Barruelian/Stephanian B, respectively) in the Cantabrian Mountains, NW Spain. These are tectonically isolated remnants of two mutually unconformable basins, which also overlie earlier Carboniferous strata (up to and including lower/middle Westphalian D) unconformably. The post-Leonian and postAsturian successions participate in the general structure of the arcuate fold belt of the Cantabrian Mountains, and are overlain, with markedly angular unconformity, by the post-"Hercynian" cover rocks which include Stephanian C/Autunian, Permian and Mesozoic/Tertiary strata. Structural lines (mainly thrust faults) are marked to show tectonic outline, and major faults are named as the Ruesga, León and Picos faults. The Ruesga Fault represents the line of maximum shortening where the Palentian area of the northern branch of the arcuate fold belt overrides the Asturian-Leonese area of the southern branch. The León Fault seems to have the same significance, and is almost in continuity with the Ruesga Fault. The Picos Fault, with identical southward movement, is much later in age, but still within the "Hercynian" structure. For the outline and position of the post-Leonian and post-Asturian outliers the Geological map of Spain (MAGNA series at scale 1:50,000) has been used as well as personal data. 
limestone area of the Picos de Europa (Fig. 1), and was described as consisting of shales and sandstones with lensing conglomerates. Its age was given as Stephanian on the basis of Callipteridium cf. gigas, a plant fossil identified by H.W.J. van Amerom and F. Stockmans. Kutterink (1966) noted its unconformable contact with the Devonian and lower Carboniferous deposits of Gildar-Montó, an older nappe structure, and mentioned thrust contacts on the other, northern side.

Maas (1974) and Maas \& Van Ginkel (1983) also dealt cursorily with the Valdeón Formation as one of the stratigraphic units bordering the Picos de Europa on its southern side. Maas (1974) compared with the unconformable Lebeña Formation in the Picos de Europa. Finally, Rodríguez-Fernández \& Heredia (1988) and Rodríguez-Fernández et al. (1990) split the Valdeón Formation of Kutterink into three informal units, viz. the Maraña, Pontón and Valdeón 'groups', which are separated by low-angle unconformities. These units are represented on the 1:50,000 geological map of Spain (Burón sheet) and are described in the explanatory memoir of this sheet (Rodríguez-Fernández et al., 1990). Apart from the inappropriate use of the word 'group', a term conventionally reserved for lithostratigraphic units of higher rank than 'formation', the restriction of the Valdeón 'group' to only part of the Valdeón Formation of Kutterink (1966) amounts to a new definition. This should have been recognised by employing a different name. Moreover, it is doubtful that the Maraña 'group' of Rodríguez-Fernández \& Heredia (1988) forms part of the Valdeón Formation as originally described by Kutterink. The Maraña beds are described as consisting of mudstones, and litharenites, with limestone breccias and olistoliths. The latter yielded faunal remains, including fusulinid foraminifera, which indicate lowermost Myachkovsky of the Upper Moscovian [equivalent to about mid-Westphalian D; (Rodríguez-Fernández et al., 1990, p. 61, mention upper Westphalian D, but this must be a slip of the pen)]. Rodríguez-Fernández et al. (1990) also assign a Westphalian D/early Cantabrian age to the Maraña unit, on the basis of floral remains collected at Riaño, further south (Alonso, 1981). However, this is clearly unwarranted since the lower Cantabrian conglomeratic deposits at Riaño are non-marine and belong to the valley fill sediments developed on the north-northwestern edge of the post-Leonian basin, which opens south-southeastwards into the Guardo Coalfield area (Iwaniw, 1985). A better comparison is with the Covarres Formation of Van de Graaff (1971), which is a turbiditic lateral equivalent of the deltaic Vergaño Formation of northeastern Palencia. It is recalled that Van de Graaff described olistoliths from the Covarres Formation. Both palaeogeographically and with regard to age, the Maraña beds of Rodríguez-Fernández and Heredia (1988) fit the Covarres Formation, which also shows similar facies. The Covarres Formation and its lateral equivalent, the Vergaño Formation, are overlain by post-Leonian deposits of various ages in northern Palencia (see Wagner \& Winkler Prins, 1985).

There is no evidence that the Maraña beds of
Rodríguez-Fernández and Heredia (i.e. the Covarres Formation of Van de Graaff) were originally included with the Valdeón Formation of Kutterink (1966). It thus seems likely that this formation in its original acceptance has only been subdivided into the Pontón and Valdeón units of Rodríguez-Fernández \& Heredia (1988). The base of the Pontón unit is regarded as unconformable by the authors of the Burón map sheet, and it is apparent from the map that this is the unconformity noted by Kutterink (1966) as determining the base of his Valdeón Formation. Rodríguez-Fernández et al. (1990) regard this contact as a 'progressive unconformity', meaning a paraconformable relationship with the Maraña beds, with overstep in part of the outcrop area. This is quite comparable to the situation in northeastern Palencia, where the Sierra Coriza limestone unit at the top of the Vergaño Formation is overlain disconformably by the post-Leonian Brañosera Formation of late Cantabrian age. The Pontón beds, c. 1,000 m thick, mainly consist of mudstones with siltstone and sandstone intercalations and laterally more or less continuous conglomerate bands as reflected by the mapping. Its turbiditic character is noted by Rodríguez-Fernández et al. (1990), and a fan delta is postulated. Although the Pontón beds are undated, they have been assigned a Cantabrian age on the basis of a comparison with apparently similar deposits that appear on the Riaño map sheet, to the south (RodríguezFernández et al., 1991). Although this is conjectural, a late Cantabrian age may be correct on the basis of a comparison with the upper Cantabrian Brañosera Formation of northeastern Palencia.

The Valdeón beds (upper part of the Valdeón Formation) are described by Rodríguez-Fernández et al. (1990) as overlying the Pontón beds with a slight unconformity. This is also apparent on the map. Both units participate in a large synclinal structure striking SW-NE and plunging NE-wards where it is partly hidden from view by surficial deposits and partly covered, with high-angle unconformity, by the Remoña beds, an undated unit, which is ascribed to Stephanian B by Rodríguez-Fernández et al. (1990) on regional geological grounds. The Remoña beds are overthrust by limestones of the Picos de Europa. On its northwestern side the Valdeón Syncline is overthrust by a variety of units in what appears to be a heavily sheared thrust zone which is bounded on the other side by a competent unit of Lower Palaeozoic quartzites.

\section{AGE AND SIGNIFICANCE OF THE VALDEÓN BEDS}

The Valdeón beds, representing the upper part of the Valdeón Formation, are at least 1,200 m thick, according to Rodríguez-Fernández et al. (1990). Most of the succession consists of poorly exposed mudstones with siltstone and sandstone layers. These alternate with quartzite conglomerate bands, 5-15 m thick, which are depicted on the map as showing good lateral continuity. Both coarsening upwards and fining upwards sequences 
have been noted by Rodríguez-Fernández et al. (1990), who also mention braided stream facies. They avoid committing themselves to either marine or fluviatile facies, but the general impression gained by the present writers is of a shallow marine environment with predominant mudstones which are apparently unfossiliferous and of a fairly homogeneous aspect. The laterally continuous conglomerate bands form rather massive beds which possibly represent deposits slid into the basin by a mass flow mechanism. No evidence of channelling has been observed. Although sedimentary structures are rare, Rodríguez-Fernández et al. (1990) mention that associated sandstone layers display trough cross-bedding. A sedimentological study is obviously desirable in view of the somewhat conflicting information.

Kutterink (1966) records the presence of thin coal beds in the upper part of the Valdeón Formation, and coals are also mentioned in the legend of the geological map (Burón sheet). Finely comminuted plant debris has been observed by Kutterink (1966), who also collected identifiable plant remains from a single locality in the highest part of the succession. These are quoted as follows: Neuropteris sp., Callipteridium cf. gigas (von Gutbier) Weiss, Lepidophyllum sp., Calamites sp. (H.W.J. van Amerom det.). Kutterink's plant locality has been visited by the present writers, who collected the following species (loc. 8713 - RHW det.):

\section{Neuropteris ovata Hoffmann \\ Callipteridium cf. zeilleri Wagner \\ Alethopteris bohemica Franke \\ Dicksonites plueckenetii (von Schlotheim) Sterzel (1) (Pl. I, fig. 5) \\ Pecopteris (Oligocarpia?) bredovii Germar \\ Pecopteris cf. paleacea Zeiller \\ Sphenophyllum oblongifolium (Germar \& Kaulfuss) Unger}

(1) The International Code of Botanical Nomenclature has imposed a starting date of 31 Dec. 1820 (Sternberg, Flora der Vorwelt, Versuch 1) for the naming of palaeobotanical taxa, thus leaving Von Schlotheim's earlier names in a legal limbo. This arbitrary decision seems rather unethical. The present writer (RHW) will continue to respect Von Schlotheim's original authorship.
This locality is close to the faulted contact with older Carboniferous strata, and seems to occur within the shear zone on the edge of the Ponga tectonic unit. Its floral assemblage is similar to that found in a newly discovered locality, which also occurs in the highest part of the Valdeón beds (loc. 8709), and which may well represent the same strata as recorded by Kutterink in what is probably a tectonic repetition. This locality occurs in a relatively undisturbed section southeast of the shear zone which delimits the Valdeón Formation near the top. It shows abundant drifted plant remains, mainly comminuted but partly identifiable. These fragments belong to only a limited number of species which are found throughout a thickness of $4 \mathrm{~m}$ of silty shales; these include a few carbonaceous layers representing the local enrichment of drifted, comminuted plant remains. There is a notable absence of rootlet beds in this shale succession, which is well exposed in a forestry road cutting. The plant-bearing shales follow upon sandstones (beds of 10-25 cm thickness) alternating with silty shales, with occasional layers showing finely comminuted plant debris on the bedding planes. The plant-bearing shales of loc. 8709 are followed in turn by a quartzite conglomerate band without apparent internal organisation.

The parallel bedding, the absence of rootlets, and the relatively small number of well preserved plant fragments (the vast majority of the larger plant remains in locality $n^{\circ}$ 8709 are poorly imprinted on the rock) as well as the high proportion of unidentifiable, comminuted plant remains, all combine to suggest deposition in a body of water, i.e. either a lagoonal or a lacustrine environment. The plant remains drifted into this environment. They are flat-lying and there is no hint of small-scale mudflow, as is common in alluvial plain deposits. Since the barren, generally homogeneous, silty mudstones in the main section of the Valdeón beds suggest a general marine environment, it seems reasonable to interpret the silty shales in the highest part of the Valdeón beds as lagoonal rather than lacustrine. The fact that the abundant plant remains in these shales only contain a relatively small proportion of identifiable foliage fragments, probably means near-coastal conditions obtained in the context of a shallowing marine basin. Assiduous collecting and selection from a large number of specimens obtained by persistent digging with pick and hammer, has yielded a

\section{Plate I}

Numbers correspond to the Valdeón collection in the Catalogue of fossil plants, Jardín Botánico de Córdoba.

1 Neuropteris ovata Hoffmann, x 6. Lateral pinnules and terminal to last order pinna. VA001. Loc. 8709.

2 Callipteridium (Eucallipteridium) zeilleri Wagner, x 6. Intercalated pinnules on a penultimate rachis. VA002. Loc. 8709.

3 Callipteridium (Eucallipteridium) zeilleri Wagner, x 3. Pinnae forming part of a penultimate pinna fragment. VA003. Loc. 8709.
4 Callipteridium (Eucallipteridium) zeilleri Wagner, x 3. Intercalated pinnules on a rachis of the penultimate order. VA004. Loc. 8709.

5 Dicksonites plueckenetii (von Schlotheim) Sterzel, x 3. Vaulted pinnules of D. sterzelii Zeiller type. VA005. Loc. 8713.

6 Alethopteris bohemica Franke, x 3. Pinnules showing somewhat pointed apices, a strongly marked midrib and crowded lateral veins perpendicular to both midrib and pinnule margin. VA006. Loc. 8709. 
Plate I

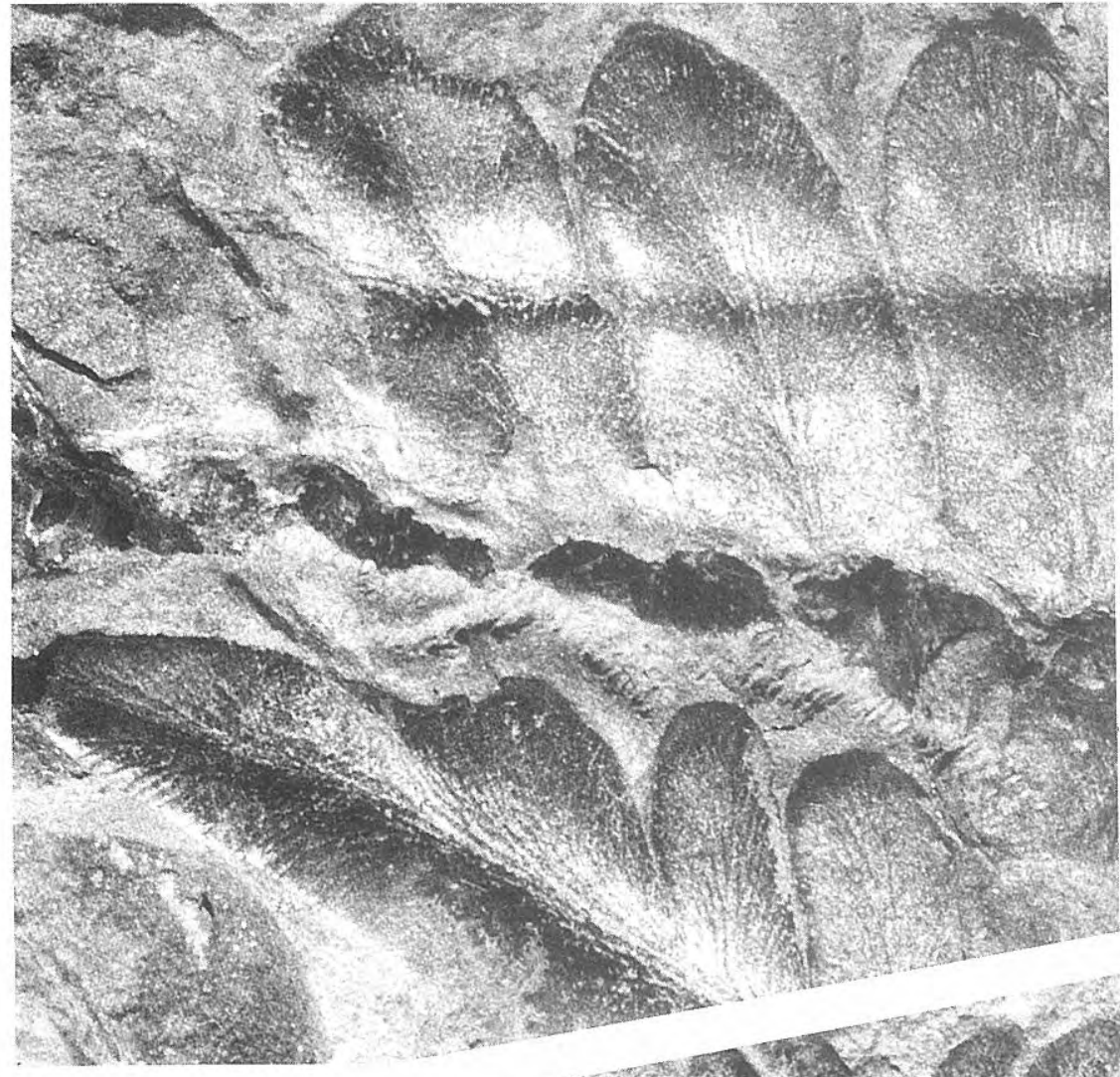

1
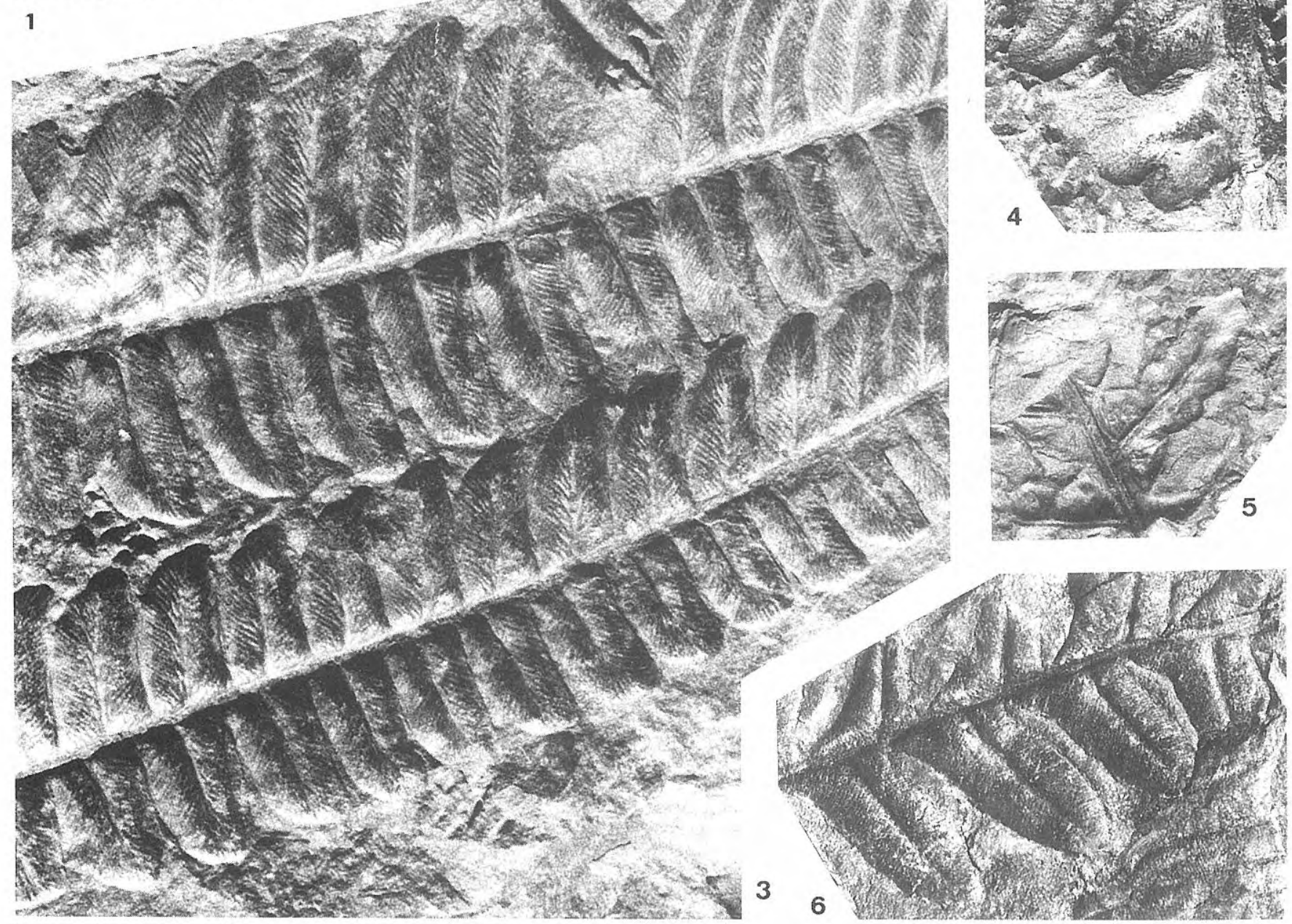

Revista Española de Paleontología, 13 (1), 1998.
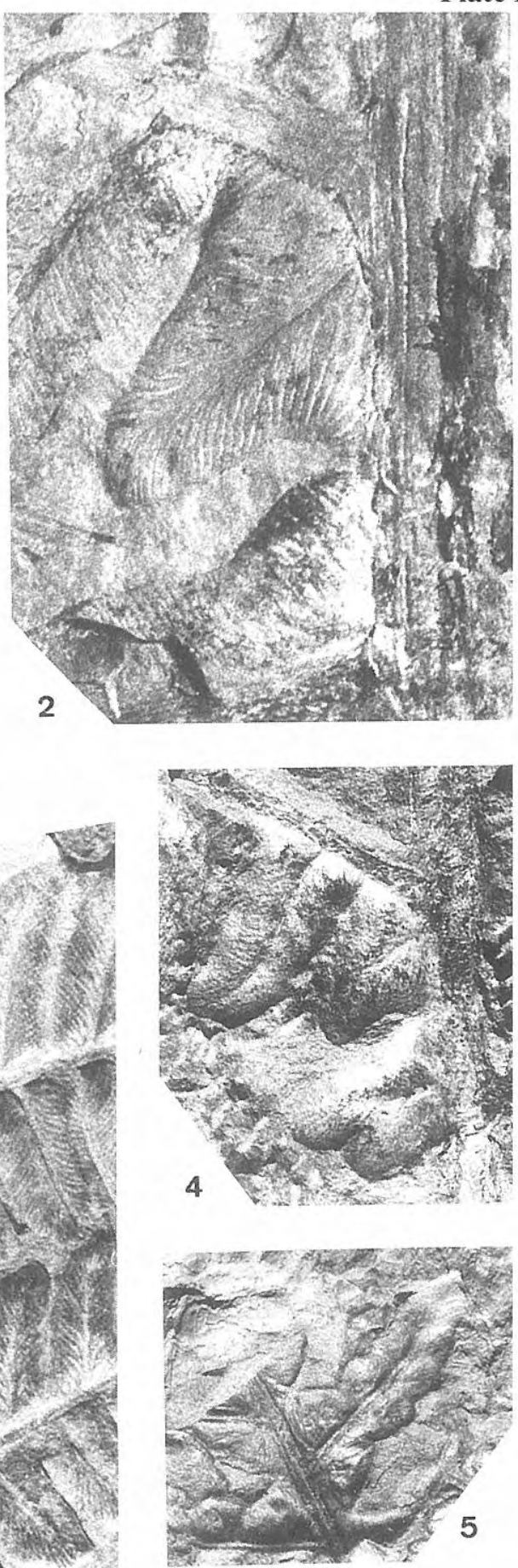
total of 100 specimens worth keeping. These belong to the following taxa (loc. 8709 - RHW det.):

Neuropteris ovata Hoffmann (Pl. I, fig. 1)

Callipteridium (Eucallipteridium) zeilleri Wagner (Pl. I, figs 2-4)

Alethopteris bohemica Franke (Pl. I, fig. 6)

Alethopteris zeilleri Ragot

Dicksonites cf. plueckenetii (von Schlotheim) Sterzel

Eusphenopteris cf. neuropteroides (Boulay) Novik

Sphenopteris sp. indet.

Pecopteris (Oligocarpia?) bredovii Germar (Pl. II, fig. 4)

Pecopteris cf. deltoidea Wagner (compare also $P$. ameromii Stockmans \& Willière)

Pecopteris sp. indet.

Sphenophyllum oblongifolium (Germar \& Kaulfuss) Unger (Pl. II, fig. 3)

As noted before, this assemblage is essentially the same as that found in Kutterink's locality, and it seems likely that the same plant-bearing shale interval is involved.

Rodríguez-Fernández et al. (1990) have assigned a Stephanian A (= Barruelian) age to the Valdeón beds, but the evidence is circumstantial, the palaeontological data being limited to Callipteridium as mentioned by Boschma \& Van Staalduinen (1968). The more substantial plant assemblage recorded in the present paper does, however, confirm Barruelian as the earliest possible age. A later Stephanian age cannot be excluded on the basis of the still rather limited assemblage collected. It is therefore necessary to use indirect evidence for a tentative age attribution of the Valdeón Formation. The various options are considered as follows.

\section{COMPARISON WITH POST-LEONIAN DEPOSITS IN NORTHERN PALENCIA}

The regional geological context is important for making an educated guess about the possible age of the top part of the Valdeón Formation. Two possibilities exist, i.e. either the Barruelian age as suggested by RodríguezFernández et al. (1991), or a later Stephanian age. In the eastern part of the Cantabrian Mountains there are two successive, mutually unconformable basins which involve Stephanian strata (Fig. 1). Although partly overlapping, they occupy two different areas. The earlier basin commenced in late Westphalian D times, and lasted throughout Cantabrian and early Barruelian times. This is the post-Leonian basin, which has been documented in detail from northern Palencia and northeastern León. A total succession of c. $5,500 \mathrm{~m}$ of strata has been recorded by means of sections measured to the scale of $1: 100$, in the context of a detailed regional stratigraphic and palaeontological study. A comprehensive summary of the basin history has been published by Wagner \& Winkler Prins (1985). Although additional work has been published, this remains the most comprehensive account in existence. Most of the fine detail is still unpublished. This basin, with mainly deltaic upper Westphalian D and lower Cantabrian deposits, experienced an important expansion in late Cantabrian times when the upper Cantabrian Brañosera Formation was deposited. This marine formation overlaps substantially on the earlier deltaic deposits, and consists of mudstones and siliciclastic turbidites with carbonate debris flow deposits (olistoliths) in the lower part of the formation. This represents an important episode of syn-sedimentary tectonic mobility, in conjunction with the expansion of the sedimentary basin. In the type section of the upper Cantabrian and the lower Barruelian in the Rubagón Valley at Barruelo de Santullán (Palencia), the almost 2,000 $\mathrm{m}$ thick succession of strata shows mainly marine deposits, with coal-bearing intervals coming in for the first time in the higher part of the upper Cantabrian (Peñacorba Member of the Barruelo Formation) and then at the conventional base of the Barruelian (Carboneros Member) and, more substantially, in the higher part of the lower Barruelian (Calero Member of the Barruelo Formation). Although terrestrial facies become predominant in the higher part of the Calero Member, lateral facies changes show the marine conditions to have lasted longer in the northwestern part of the basin. It is by no means inconceivable that the Valdeón Formation south of the Picos de Europa represents the seaward part of the expanded post-Leonian basin, and that the unconformity at the base of the Valdeón Formation (Pontón beds) equates to the unconformity at the base of the Brañosera Formation in northern Palencia. This interpretation is coherent with the largely marine facies of both the Brañosera Formation and successive Barruelo Formation. The introduction of coal-bearing facies in the upper part of this upper Cantabrian and lower Barruelian succession compares with the apparently lagoonal, plantbearing strata near the top of the Valdeón Formation, following upon a marine section. In both cases there is a regressive tendency upwards (as a result of basin fill?). Compare Fig. 2.

$\begin{array}{lll}\text { Stages } & \text { NE Palencia } & \text { NE León } \\ \text { Barruelo Formation } \\ \text { Calero Member } \\ \text { Polvorín Member }\end{array} \quad$ Valdeón beds

lower CANTABRIAN and upper WESTPHALIAN D missing

lower WESTPHALIAN D Covarres Formation Maraña beds (= lateral equivalent of Vergaño Formation)

Figure 2. Probable equivalence of lithostratigraphic units in northeastern Palencia (Rubagón Valley, Barruelo Coalfield, and Redondo Valley, Barruelo Syncline) and those in the Valdeón area of northeastern León. 


\section{COMPARISON WITH POST-ASTURIAN SUCCESSIONS}

The floral assemblage found in the top part of the Valdeón Formation also allows a comparison with higher Stephanian strata as occur in the post-Asturian basin of NW Spain. This involves a string of almost exclusively terrestrial, coal-bearing areas following the outline of the Upper Palaeozoic arcuate fold belt in northern León and western Asturias, and also an area of predominantly marine facies in eastern Asturias (Fig. 1). The former consists of tectonically isolated coalfields with sediments which reflect the proximity of an active, rising hinterland, whereas the latter area coincides with a tectonic foreland with a generally lower rate of sedimentation. South of Valdeón, in northern León, the nearest post-Asturian strata are in the Sabero Coalfield and the Rucayo strip (Fig. 1). The coal-bearing sediments of the Rucayo strip occur in a narrow E-W striking band of strata which are associated with the León Fault, a tectonic fracture zone which is interpreted differently by the different authors, but which represents major shortening and is therefore likely to have been originally a thrust fault. Although affected by faulting, the Stephanian strata of the Rucayo strip (as dated by Wagner, 1963, and Van Amerom, 1965) are described as basically unconformable and are thus regarded as later than the primary movements on this fault. Fossil floras from the Rucayo strip are middle to upper Stephanian, without further precision. A description of sedimentary facies in the Rucayo strip is given by Santos et al. (1990) and, in more summary fashion, in the memoir of the Riaño map sheet (Rodríguez-Fernández et al., 1991, p. 87-88). The limited succession described (about $200 \mathrm{~m}$ ) seems to correspond exclusively to terrestrial facies associated with alluvial fans and related alluvial plain deposits. A much more complete succession is known for the Sabero Coalfield, c. $11 \mathrm{~km}$ south of the Rucayo strip. The geology of this coalfield has been described in detail by Knight (1983a), who records a total of 2,500 m of strata of late Barruelian and Stephanian B (sensu Carmaux) ages. These show pronounced onlap westwards, in the direction of the Ciñera-Matallana Coalfield, also in northern León (Fig. 1). A small interval of marginally marine deposits has been recorded from the lower part of the Raposa Formation, the first widespread lithostratigraphic unit in the Sabero Coalfield. This formation overlaps an initial basin sag as represented by the strictly local Alejico beds. Both formations are late Barruelian in age, and they overlie previously deformed lower Cantabrian strata of the earlier, post-Leonian basin unconformably (Iwaniw \& Knight, 1981). Upper Cantabrian and lower Barruelian strata were apparently eliminated by erosion prior to the unconformity (several thousand metres of strata representing the missing ages are known further east, in the same post-Leonian basin). Apart from the shallow marine strata in the lower part of the Raposa Formation, the succession found in the post-Asturian Sabero Coalfield is terrestrial, with alluvial fan and alluvial plain deposits alternating with fairly major lacustrine intervals, a characteristic shared with the Stephanian B succession in the adjacent Ciñera-Matallana Coalfield (Wagner, 1971), some $12 \mathrm{~km}$ westwards in northern León.

Tectonic deformation by folding and the possibility of repeated movements on the León Fault in northern León means tectonic shortening. The Valdeón Formation outcrops at some $42 \mathrm{~km}$ NNE of Sabero, but may have been further away originally. Heward (1978) interpreted the Sabero and Ciñera-Matallana post-Asturian successions as having been formed under the influence of alluvial fans linked to a rising hinterland to the south and southwest. The similar facies of the Rucayo strip either means local control as postulated by Santos et al. (1990), or an encroachment of the hinterland area in the later part of the basin history.

The presence of major lacustrine intervals in relatively well dated strata has allowed a correlation to be proposed between the successions at Sabero and at CiñeraMatallana (Knight, 1983a). Sedimentation at CiñeraMatallana commenced later as a result of onlap. It is possible that the episodes of widespread ponding on the alluvial plain corresponded to marine transgressions in the northern part of the general basin, where it was open to the sea. Such transgressions would have produced a rise in groundwater level. Although marine transgressions of a eustatic nature are known to have occurred in late Carboniferous (Pennsylvanian) times, the high rate of sedimentation in the Stephanian coalfields of NW Spain (generally in excess of a thousand metres per million years) points at tectonic mobility as the most probable cause. It is quite possible that tectonic subsidence operated in pulses, and thus provoked repeated transgression. A direct marine connection has been proved at Sabero where the lower part of the Raposa Formation contains very shallow marine deposits with brackish shell bands (Knight, 1983a). The presence of several thousand metres of apparently marine strata in the Valdeón Formation, well to the north of the hinterlandcontrolled coal-bearing successions of Sabero and Ciñera-Matallana, is compatible with the general setting of a quickly subsiding basin bordering a southern hinterland and extending northwards into the sea which linked the Cantabrian area of deposition to the Palaeotethys. The Valdeón Formation might thus represent the northward progradation of sediments into the marine part of the post-Asturian basin. This is the alternative hypothesis to the possible link with the postLeonian basin after its late Cantabrian expansion, as discussed earlier. In order to test this alternative hypothesis it is necessary to discuss the post-Asturian succession in eastern Asturias.

\section{FONTECHA OUTLIER NORTH OF BELEÑO (ASTURIAS)}

Some $20 \mathrm{~km}$ northwest of the outcrop area of the Valdeón Formation, an unconformable succession of terrestrial strata followed by marine deposits is found in the Sierra de Fontecha, north-northwest of the regional 
centre, San Juan de Beleño, in eastern Asturias (Fig. 1). This succession, first reported by Julivert (1961), is shown on the Rioseco geological map sheet (RodríguezFernández et al., 1989) as being in continuity with marine Stephanian strata south of Vega de Sebarga. However, in fact, two different successions seem to be involved, probably with a low-angle unconformity in between. The sedimentological characteristics of several sections of the succession found south of Vega de Sebarga have been described by Colmenero \& Bahamonde (1986), who recorded marine facies ascribed to a fan delta. The sediments involved are mainly mudstones, with debris flow conglomerates and limestones. The latter yielded fusulinid foraminifera (Villa, in Martínez-García et al., 1985; and in Colmenero \& Bahamonde, 1986). These correspond to the Krevyakinsky Horizon of the lower Kasimovian (Villa, pers. comm.), which equates to upper Cantabrian according to Wagner \& Winkler Prins (1985). Less than $200 \mathrm{~m}$ of section would be present.

The succession in the Sierra de Fontecha is rather different. Colmenero \& Bahamonde (1986) only provide a brief description, and refer to channelised subaerial deltaic deposits. Julivert (1961, p. 92) recorded this succession as commencing with a conglomeratic interval of $22 \mathrm{~m}$, followed by $40 \mathrm{~m}$ of quartzitic sandstones, and $100 \mathrm{~m}$ of shales and sandstones with coal at the base. This description does not agree with the succession as seen by the present writers, and it may be that it was recorded upside down. Exposures in the coal-bearing interval, near the base of the succession, show mainly mudstones with a few sandstone bands, which increase in importance upwards. The lower part of the coal-bearing interval, which is estimated as being only some $20 \mathrm{~m}$ thick, consists mainly of rootlet beds, thus clearly displaying a terrestrial facies. Drifted plant remains, mainly comminuted but partly comprising identifiable fragments (loc. 9594, see further on), occur above the mudstones with rootlets and thin coal bands which have been worked in the past (apparently up to the 1950s). Higher up, cross-bedded sandstones and conglomerates occur (with some highly characteristic trace fossils in at least one sandstone band), and these are followed by mudstones with sparse sandstone bands and debris flow conglomerates. Marine bivalves and gastropods occur in these higher beds which are exposed in a stream cutting in the woods near the Moandi col. The basal part of the total succession, below the coal-bearing interval, has not been found exposed.

Julivert (1961) collected from the tip of the Fontecha coal mine, and found a reasonably well diversified flora which was identified by F. Stockmans and R.H. Wagner as follows (Wagner, 1965, p. 41): Linopteris neuropteroides (von Gutbier) Potonié, Linopteris florinii Teixeira, Callipteridium zeilleri Wagner, Dicksonites plueckenetii (von Schlotheim) Sterzel forma sterzelii Zeiller, Sphenopteris sp., Polymorphopteris polymorpha (Brongniart) Wagner, Pecopteris candolleana Brongniart, Pecopteris lepidorachis Brongniart, Pecopteris cyathea (von Schlotheim) Brongniart, Sphenophyllum oblongifolium (Germar \& Kaulfuss) Unger, Sphenophyllum cf. angustifolium Germar, Annularia stellata (von Schlotheim) Wood, Calamostachys tuberculata (Sternberg) Weiss, Calamites schuetzei Stur. A further list of plant fossils, as identified by J.P. Laveine, was given in the memoir accompanying the Rioseco map sheet (RodríguezFernández et al., 1989, p. 54). This list of species is transcribed here without the numerous spelling mistakes: Neuropteris ovata Hoffmann, Odontopteris (= Lescuropteris) genuina Grand'Eury, Callipteridium zeilleri Wagner, Dicksonites plueckenetii (von Schlotheim) Sterzel, Eusphenopteris sp., Renaultia chaerophylloides (Brongniart) Zeiller, Pecopteris (= Polymorphopteris) polymorpha Brongniart, Pecopteris hemitelioides Brongniart, etc. This locality mentioned as being near the Moandi col has been looked for by the present writers, but seems to be overgrown.

The present writers revisited the site of the long abandoned Fontecha mine, and collected the following plant fossils from the coal tip washed out by a mountain stream (loc. 6893 - RHW det.):

\section{Neuropteris ovata Hoffmann \\ Linopteris gangamopteroides (de Stefani) Wagner (probably the same as Linopteris florinii of the earlier list) (Pl. II, fig. 2) \\ Callipteridium zeilleri Wagner \\ Dicksonites plueckenetii (von Schlotheim) Sterzel \\ Pecopteris candolleana Brongniart \\ Pecopteris spp. \\ Sphenophyllum oblongifolium (Germar \& Kaulfuss) Unger \\ Annularia stellata (von Schlotheim) Wood}

Fragments of mudstone with marine bivalves were found associated, but these probably correspond to the higher part of the section traversed by a mine cross-cut.

If the presence of Sphenophyllum angustifolium could be confirmed, it would mean a high Stephanian level, probably Stephanian B sensu stricto, as defined by Jongmans \& Pruvost (1950) in the St Etienne basin of the French Massif Central. Unfortunately, the whereabouts of

\section{Plate II}

Numbers correspond to the Fontecha and Valdeón collections in the Catalogue of fossil plants, Jardín Botánico de Córdoba.

1 Pseudomariopteris busquetii (Zeiller) Danzé-Corsin, x 3. Near-terminal fragment of a pinna of the penultimate order. FO001. Loc. 9594 (Sierra de Fontecha).

2 Linopteris gangamopteroides (de Stefani) Wagner, x 6. Detached pinnule. FO002. Loc. 6893 (Sierra de Fontecha).
3 Sphenophyllum oblongifolium (Germar \& Kaulfuss) Unger, x 6. Trizygoid leaf whorls. VA008. Loc. 8709.

4 Pecopteris (Oligocarpia?) bredovii Germar, x 6. Part of a last order pinna. VA009. Loc. 8709. 
Plate II

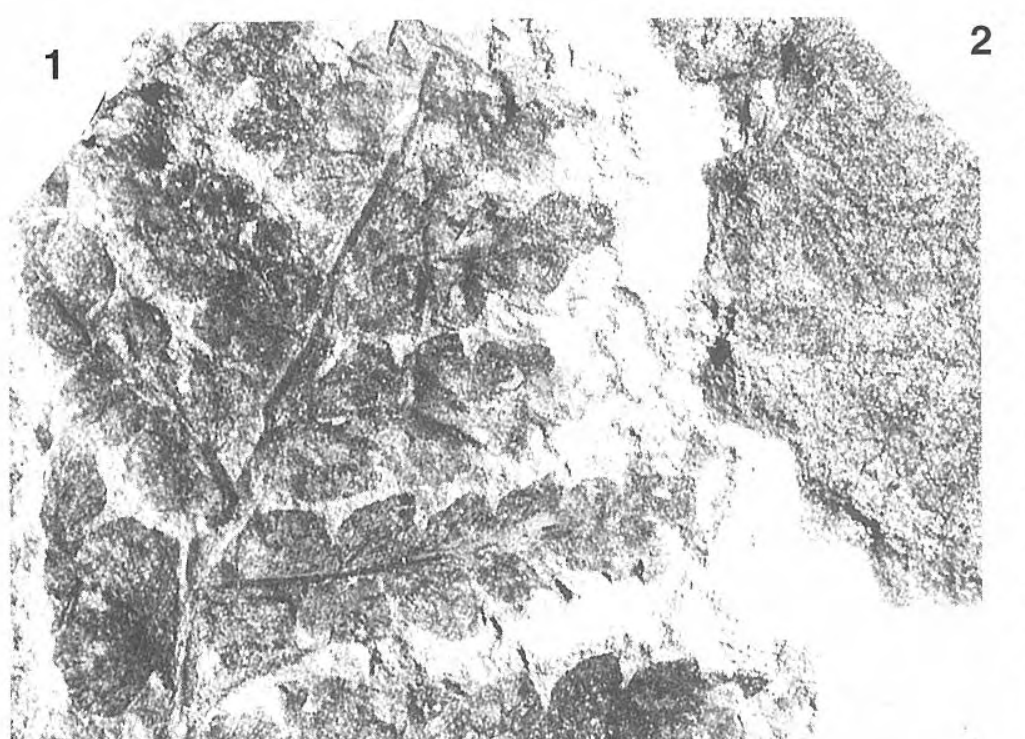

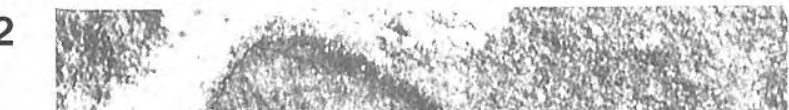

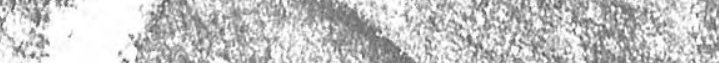

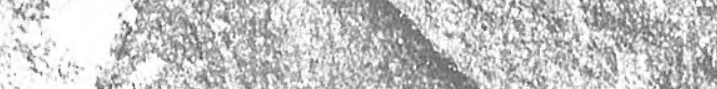

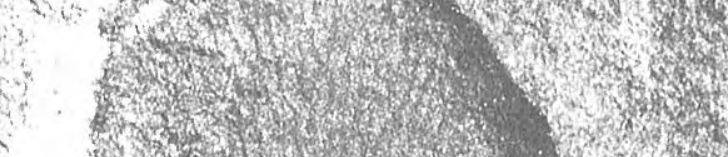
. 4
4
4

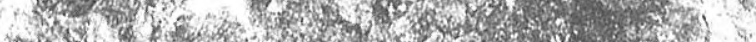
19t.

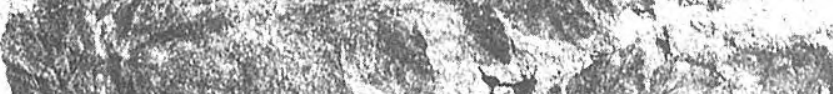

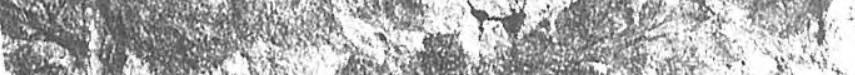
7. H

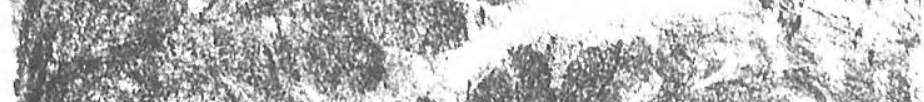

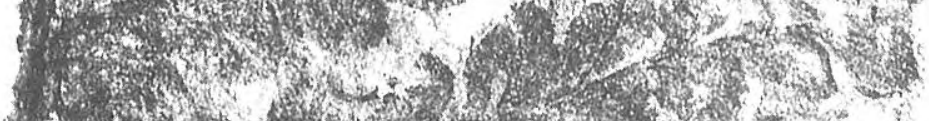

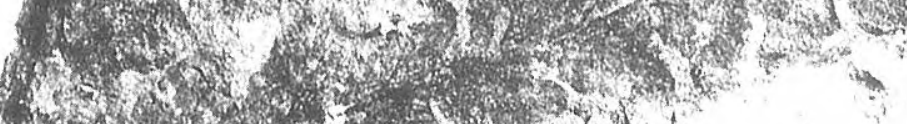

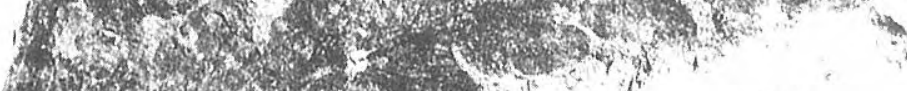

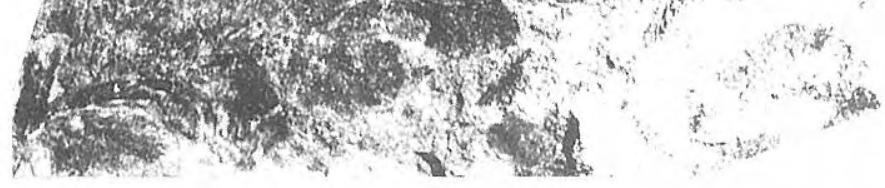
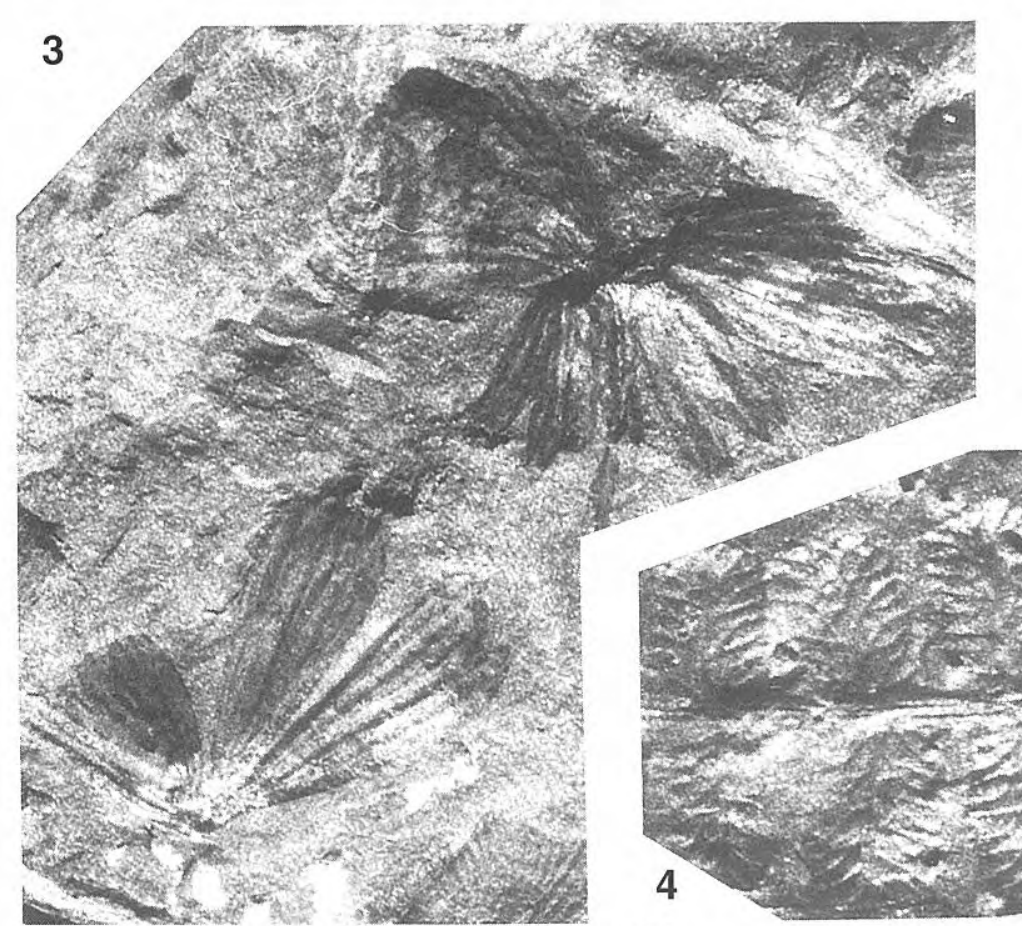
Julivert's collection are unknown, and it is not currently possible to check on the identifications.

A new outcrop locality of shales in the coal-bearing interval in the Sierra de Fontecha, has yielded a substantial collection of plant impressions. The following species are identified by R.H.W. (loc. 9594):

Neuropteris cf. ovata Hoffmann

Neuropteris praedentata Gothan

Neuropteris cf. obtusa (Brongniart) Wagner \& Castro

Neuropteris zeilleri Lima

Lescuropteris genuina (Grand'Eury) Remy \& Remy

Reticulopteris germari (Giebel) Gothan

Alethopteris $\mathrm{cf}$. zeilleri Ragot

Callipteridium zeilleri Wagner

Pseudomariopteris busquetii (Zeiller) Danzé-Corsin (Pl. II, fig. 1)

Dicksonites plueckenetii (Schlotheim) Sterzel

Sphenopteris (Dicksonites?) decorpsii Zeiller

Oligocarpia gutbieri Göppert

Sphenopteris fayolii Zeiller

cf. Renaultia gracilis (Brongniart) Zeiller

cf. Senftenbergia sp.

Pecopteris sp. cf. paleacea Zeiller

Pecopteris cf. candolleana Brongniart

Sphenophyllum oblongifolium (Germar \& Kaulfuss) Unger

Annularia sphenophylloides (Zenker) Gutbier

Annularia spicata Gutbier

Annularia stellata (Schlotheim) Wood

Annularia sp.

Asterophyllites sp.

This flora is varied and well preserved, but the specimens are fragmentary. Further collecting is desirable before a full documentation should be attempted. The above list is therefore regarded as preliminary. Among the taxa recorded, Pseudomariopteris busquetii and Annularia spicata suggest a high Stephanian level, equivalent to the angustifolium Zone of Wagner (1984) or higher. The assemblage presents a mixture of hygrophile and mesophile elements, so there is a certain amount of transport involved. This also explains the fragmentation. On the other hand, there is sufficient variety to suggest that transport selection did not operate to a significant extent.

In the case of this flora, of late Stephanian age, either Stephanian B (sensu St. Etienne) or C, one can exclude comparison with the post-Leonian basin in northern Palencia. Even within the post-Asturian succession, a quite considerable onlap relationship with regard to the initial basin at Sabero must be considered to explain such a late Stephanian age right at the base of the unconformable succession.

\section{ARENAS DE CABRALES (EASTERN ASTURIAS)}

A comparable succession to that found in the Sierra de Fontecha occurs north of the present-day orographic region of the Picos de Europa, an area where carbonate platform conditions lasted into the early to mid-Kasimovian Krevyakinsky and Khamovnichevsky (Martínez-García \& Villa, 1986; Villa \& Martínez-García, 1989; Villa, 1995). High Stephanian deposits exist in an elongate outcrop area extending across Arenas de Cabrales (Fig. 1). These postAsturian deposits overstep lower Stephanian, post-Leonian strata with low-angle unconformity. At Arenas de Cabrales they have come to rest on Moscovian limestone, which they overlie with an irregular contact, presenting the aspect of a palaeokarst. The succession at Arenas de Cabrales, as described by Martínez-García \& Wagner (1971), commences with predominantly sandy terrestrial deposits, which include a thin coal seam with its underlying rootlet bed and plant-bearing roof shales. This interval of terrestrial facies, only about $25 \mathrm{~m}$ thick, is followed by marine deposits leading into the Puentellés Limestone (Martínez García, 1981, 1991) and, higher up, into the turbiditic siliciclastic deposits of the Cavandi Formation (Martínez-García \& Wagner, 1982). The floral assemblage found in the roof shales of the thin coal in the lower part of the succession at Arenas de Cabrales shows largely the same taxa as occur in the highest part of the Valdeón Formation, viz. Neuropteris ovata Hoffmann, Callipteridium (Eucallipteridium) gigas (von Gutbier) Weiss, Callipteridium (Eucallipteridium) zeilleri Wagner, Alethopteris bohemica Franke, Dicksonites plueckenetii (von Schlotheim) Sterzel, Eusphenopteris cf. neuropteroides (Boulay) Novik, Pecopteris melendezi Wagner, Pecopteris paleacea Zeiller, Pecopteris unita Brongniart, Pecopteris spp., Sphenophyllum oblongifolium (Germar \& Kaulfuss) Unger, Annularia sphenophylloides (Zenker) von Gutbier, Calamostachys tuberculata (Sternberg) Weiss, Cordaites sp. This assemblage has been regarded as representing either Stephanian A (= Barruelian) or Stephanian B (Martínez-García \& Wagner, 1971). The plant collection reported in 1971, seems to have been lost, but the more important specimens are figured in MartínezGarcía \& Wagner (1971). A more recent collection made in the same locality immediately south of Arenas de Cabrales, has yielded material of the following species (loc. 9586 - RHW det.):

\section{Neuropteris ovata Hoffmann}

Callipteridium gigas (von Gutbier) Weiss

Alethopteris bohemica Franke

Eusphenopteris cf. neuropteroides (Boulay) Novik

Pecopteris ameromii Stockmans \& Willière

Diplazites unitus (Brongniart) comb. nov. (Basionym: Pecopteris unita Brongniart)

Sphenophyllum oblongifolium (Germar \& Kaulfuss) Unger

Sphenophyllum sp. (cf. verticillatum (Schlotheim) Zeiller)

Annularia sphenophylloides (Zenker) von Gutbier

Annularia sp.

Calamostachys tuberculata (Sternberg) Weiss

A non-marine bivalve comparable to Anthraconaia prolifera Waterlot was found in association. Spirorbis 
pusillus Martin also occurs. As might be expected, this assemblage is identical to that recorded in 1971. A Stephanian B age or higher may be deduced.

Fusulinid foraminifera in the Puentellés Limestone and in (endo-) olistoliths of the Cavandi Formation show a late Kasimovian (Dorogomilovsky) age (Villa, 1995). These are the highest fusulinid-bearing limestones in the Cantabrian Mountains.

It is noted that the stratigraphic succession at Arenas de Cabrales shows a similar development to that of Fontecha, viz. terrestrial strata including coal, at the base, and a fully marine section higher up. This is the reverse development to that seen at Valdeón, where an apparently marine succession shallows upwards into near shore sediments with drifted plant remains.

\section{CONCLUSIONS}

The Valdeón Formation of Barruelian or later age in its highest part apparently represents a marine basin that shallowed upwards without quite making it into subaerial conditions. The known succession is altogether at least 2,200 $\mathrm{m}$ thick, according to Rodríguez-Fernández et al. (1990). Its overall development allows comparison with the succession of strata at Barruelo de Santullán (Palencia) where the Brañosera and Barruelo formations, of comparable thickness $(2,000 \mathrm{~m})$, also show progressive shallowing upwards, although in this case terrestrial strata were developed in the higher part of a predominantly marine section. The upper part of the section at Barruelo is of early Barruelian age. If the general comparison holds, the Valdeón Formation may be considered the northern part of the expanded postLeonian basin in its latest phase of development, i.e. from late Cantabrian onwards into early Barruelian. This conforms to the tentative correlation proposed in Heredia et al. (1990, fig. 3). It is recalled that the Brañosera Formation represents a widespread transgression and a very substantial expansion of the sedimentary basin. This would have reached as far as the Valdeón area (Fig. 1).

The predominantly marine, post-Asturian succession in eastern Asturias, as represented in the Sierra de Fontecha and at Arenas de Cabrales, shows a different stratigraphic development, with a minor thickness of terrestrial strata in the basal part of the succession being followed by a fully marine succession. This includes the Puentellés Limestone in the Cabrales strip. The floral assemblages recorded from Fontecha and Arenas de Cabrales are similar in part to the one found near Valdeón, but could well be substantially later in age. The megafloral assemblages recorded from Fontecha are "late" Stephanian B or Stephanian C in age.

\section{COMMENTS ON CHRONOSTRATIGRAPHY}

The recent revision of fossil floras from the St Etienne basin in the French Massif Central (Doubinger et al.,
1995) has shown that the Stephanian B of this basin contains floras of the Sphenophyllum angustifolium megafloral zone of Wagner (1984). On the other hand, Stephanian B as it has been used in the Cantabrian Mountains, is based on a comparison with "lower" Stephanian B as represented by the Tronquié beds at Carmaux, another basin in the Massif Central. This interval (Stephanian B sensu Carmaux) is apparently missing at St Etienne, where a stratigraphic gap linked to an unconformity separates Stephanian A from Stephanian B (sensu stricto). This means that the Stephanian "B" of the Cantabrian Mountains, which is in continuity with Barruelian (Stephanian A sensu lato), will have to be renamed in accordance with the rules of stratigraphic nomenclature, and its boundary defined with reference to a stratotype. It is noted that the St Etienne basin, which has been used to define Stephanian A, B and C (Jongmans \& Pruvost, 1950), is unsuitable for stratotypic purposes since Stephanian A and B in this basin are both floored by an unconformity, and a stratigraphic gap exists between these two units. A special paper will be devoted to the stages in the Stephanian Series as developed in the Massif Central of France and the Cantabrian Mountains in Spain (Wagner in prep.) (see Fig. 3).

\section{PALAEOBOTANICAL COMMENTS (RHW)}

The floral assemblage recorded from the highest Valdeón beds in northern León, and those found at Fontecha and at Arenas de Cabrales, both in eastern Asturias, are reasonably similar. Particularly those of Valdeón and Arenas de Cabrales share a number of taxa, most notably Callipteridium zeilleri, Alethopteris bohemica, Dicksonites plueckenetii, Eusphenopteris cf. neuropteroides, and Sphenophyllum oblongifolium. Apart from Eusphenopteris neuropteroides, which is more common in Westphalian strata, these are all standard Stephanian species. Alethopteris bohemica and

$\underline{\text { Stages }}$ previous usage in the Cantabrian Mts

Stephanian C upper Stephanian C

Stephanian B (sensu St Etienne)

Stephanian B (sensu Carmaux) lower Stephanian C

Stephanian B

Barruelian

Barruelian (= Stephanian A sensu lato)

Cantabrian

Cantabrian

Figure 3. Table showing the different stages in the Stephanian Series and the use of these stages in the Cantabrian Mountains (prior to the present paper). 
Sphenophyllum oblongifolium commence their range in the lower Cantabrian. Callipteridium zeilleri occurs from Barruelian upwards, and the general impression of the assemblages found at Valdeón and Arenas de Cabrales is "standard" Stephanian. A more exact appreciation is difficult in view of the limited number of taxa found in the Valdeón beds. The same limitations are noted with regard to the floral assemblage at Arenas de Cabrales, whereas the megafloral remains collected most recently at Fontecha show a more varied assemblage, including the stratigraphically important taxa Pseudomariopteris busquetii and Annularia spicata. These species suggest a high Stephanian level, i.e. Stephanian B (sensu St Etienne) or Stephanian C. Other species found at Fontecha include Neuropteris praedentata, Lescuropteris genuina, and Reticulopteris germari. Although these species also suggest a high Stephanian level, these are regarded as probable mesophile elements, which are linked to a better drained habitat. This limits their stratigraphic value in a zonation scheme that is based primarily on taxa representing a wetter environment. Nonetheless, the sum total of floral elements found at Fontecha favours a Stephanian B age sensu St. Etienne (Fig. 3) or even later.

The pecopterid species identified at Valdeón, Fontecha, and Arenas de Cabrales are mainly tentative determinations. With the exception of the material from the Sierra de Fontecha, the specimens collected are quite fragmentary, and this imposes limitations on the identifications of species. From the two localities in the single fossiliferous band in the Valdeón beds only a few pecopterid specimens were collected among the many pteridosperm remains (mainly Alethopteris bohemica). This is presumably due to the thicker cuticles and consequently stronger cohesion of the pteridosperm pinnules, thus making them more resistant to prolonged maceration in water. The predominance of pteridosperm remains thus reinforces the impression of a drifted assemblage, in which transport selection played a major role. The more delicate fern foliage (sphenopterids and pecopterids) probably disintegrated more readily with prolonged residence time in water, and this would explain the paucity of their remains at Valdeón and at Arenas de Cabrales. On the other hand, the more delicate sphenopterid foliage remains are present in the Fontecha locality $n^{\circ} 9594$, which overlies rootlet beds and which may be more nearly parautochthonous. No terminals have been preserved for the sparse pecopterid foliage remains in the Valdeón beds, and this removes one of the characters to be used for the identification of species.

The fragment identified tentatively as Pecopteris deltoidea Wagner (unfigured) shows rather small, relatively broad pinnules with strongly marked simple veins, as is commonly the case with this pinnule size. In the absence of a pinna terminal this specimen may also be compared with Pecopteris monyi Zeiller and Pecopteris ameromii Stockmans \& Willière. It is too poorly preserved to be figured. Another pecopterid specimen with simple veins is comparable to the remains figured as Pecopteris paleacea Zeiller in Martínez-García \& Wagner (1971). It shows narrower, strongly vaulted pinnules. This form is also present at Fontecha. An additional fragment from Valdeón shows a faint nervation pattern which suggests that it belongs to the same species as the Pecopteris cf. paleacea mentioned above.

Two fragments from Valdeón are identified as the fern Pecopteris (Oligocarpia?) bredovii Germar (Pl. II, fig. 4), which Brousmiche (1983) has placed in synonymy with Oligocarpia gutbieri Göppert, although expressing an element of doubt. Whereas these rare fern fragments are rather difficult to identify due to the smallness of these remains, the much more common, sturdier pteridosperm remains are more easily identifiable. The vaulted pinnules of Alethopteris bohemica Franke (P1. I, fig. 6), which are joined by a narrowly confluent base, are totally characteristic of this species. They are wider than the more slender pinnules of Alethopteris virginiana Fontaine \& White (synonym: Alethopteris leonensis Wagner), which also do not show such a strongly marked midrib. The small apical pinnule is also characteristic of Alethopteris bohemica. Only one specimen of Alethopteris zeilleri Ragot ex Wagner has been found in the Valdeón beds. This shows a less strongly marked midrib, and its pinnules possess a more rounded apex, as well as veins that are more widely apart than the very densely arranged lateral veins of Alethopteris bohemica. This specimen is too fragmentary to be illustrated.

Neuropteris ovata Hoffmann (Pl. I, fig. 1) is also a common element in the Valdeón localities. This species, which occurs throughout the Stephanian in NW Spain, is characterised by its auricled pinnules which become gradually fused to the rachis in the near-terminal parts of pinnae. Its nervation shows variations, which are partly related to the pinnule width. In about mid-Stephanian the broader pinnules show more densely arranged lateral veins that reach the pinnule margins at approximate right angles. This is not the case with the specimens in hand which show the veins reaching the pinnule margin obliquely.

Callipteridium zeilleri Wagner (P1. I, figs. 2-4) is well represented at Valdeón. It shows the intercalated pinnules (Pl. I, figs. 2, 4) that mark it as Eucallipteridium, with a stratigraphic range from Barruelian upwards.

Dicksonites plueckenetii (von Schlotheim) Sterzel (Pl. I, fig. 5) occurs with the strongly lobate pinnules that are often associated with the var. sterzelii Zeiller. The specimens from the Valdeón beds show the vaulted pinnules that commonly occur in this variety. The Dicksonites leptophylla Doubinger form (with somewhat less vaulted pinnules), which is probably Dicksonites plueckenetii sensu stricto as found in its type locality at Kammerberg (Manebach beds) in Thuringia, does not apparently occur in the Valdeón beds.

Eusphenopteris neuropteroides (Boulay) Novik is too poorly preserved in the Valdeón localities to allow it to be illustrated. Although the identifications seems reasonably secure, the specimens involved are too fragmentary to allow an undisputable determination.

Sphenophyllum oblongifolium (Germar \& Kaulfuss) Unger (Pl. II, fig. 3), a common Stephanian species, is 
only sparingly represented in the Valdeón localities. However, the few reasonably well preserved specimens show the characteristic, slightly biconvex leaves with rather elongate teeth on the distal margin, and the anisophylly known as the trizygoid form.

A pinnule of Linopteris gangamopteroides (de Stefani) Wagner is figured (Pl. II, fig. 2) from Fontecha in eastern Asturias, to show this highly characteristic species which has been consistently misidentified as Linopteris brongniartii (Gutbier) Potonié in the French Massif Central (compare Wagner \& Sousa, 1982, Knight, 1983b, and Doubinger et al., 1995).

\section{ACKNOWLEDGEMENTS}

The authors are grateful to Professors J.P. Laveine and J. Truyols for perceptive reviews that have been most helpful for the improvement of the final version of this paper. Dr E. Villa is thanked for mentioning the early Kasimovian (Krevyakinsky) age of the (post-Leonian) strata near Vega de Sebarga. Dr M.L. Martínez-Chacón has made pertinent remarks that have led to improvements in the presentation of factual information.

\section{REFERENCES}

Alonso, E. 1981. Estudio geológico de la zona de RiañoValdeburón (León, Noroeste de España). Tierras de León, 43-44, $30 \mathrm{pp}$.

Amerom, H.W.J. van. 1965. Note préliminaire sur quelques flores stéphaniennes de la bordure nord des Léonides dans les Montagnes Cantabriques (Espagne du NordOuest). Leidse Geologische Mededelingen, 32, 151-156.

Boschma, D. 1968. Provisional geological map of the southern Cantabrian Mountains (Spain). Leidse Geologische Mededelingen, 43, 217-220, geol. map.

Boschma, D. and Staalduinen, C.J. van. 1968. Mappable units of the Carboniferous in the southern Cantabrian Mountains. Leidse Geologische Mededelingen, 43, 221-232.

Brousmiche, C. 1983. Les Fougères sphénoptéridiennes du Bassin Houiller Sarro-Lorraine (SystématiqueStratigraphie). Publication Société Géologique du Nord, 10, 480 pp.

Colmenero, J.R. y Bahamonde, J.R. 1986. Análisis estratigráfico y sedimentológico de la Cuenca estefaniense de Sebarga (Región de Mantos, Z. Cantábrica). Trabajos de Geología, 16, 103-119.

Doubinger, J., Vetter, P., Langiaux, J., Galtier, J. et Broutin, J. 1995. La flore fossile du bassin houiller de SaintEtienne. Mémoires du Muséum National d'Histoire Naturelle, 164. Paléobotanique, 355 pp.

Graaff, W.J.E. van de. 1971. Three Upper Carboniferous, limestone-rich, high-destructive, delta systems with submarine fan deposits, Cantabrian Mountains, Spain. Leidse Geologische Mededelingen, 46, 157-235, geol. map and sections.

Heredia, N., Rodríguez-Fernández, L.R. and Wagner, R.H. 1990. Carboniferous of the Palentian Zone. In: Pre-
Mesozoic Geology of Iberia (Eds. R.D. Dallmeyer \& E. Martínez-García). Springer Verlag. Berlin-Heidelberg, 34-38.

Heward, A.P. 1978. Alluvial fan and lacustrine sediments from the Stephanian A and B (La Magdalena, CiñeraMatallana and Sabero) coalfields, northern Spain. Sedimentology, 25, 451-488.

Iwaniw, E. 1985. The sedimentology of lower Cantabrian basin margin deposits in NE León, Spain. In: Papers on the Carboniferous of the Iberian Peninsula (Eds. M.J. Lemos de Sousa \& R.H. Wagner). Anais da Faculdade de Ciências, Universidade do Porto, Supplement to Volume 64 (1983), 49-115.

Iwaniw, E. and Knight, J.A. 1981. Evidence for the Asturian unconformity near Santa Olaja de la Varga, NE León, Spain. Breviora Geológica Astúrica, 25 (3-4), 17-25.

Jongmans, W.J. et Pruvost, P. 1950. Les subdivisions du Carbonifère continental. Bulletin Société géologique de France, (5), 20, 355-344.

Julivert, M. 1961. Estudio geológico de la cuenca de Beleño. Valles altos del Sella, Ponga, Nalón y Esla, de la Cordillera Cantábrica. Boletín Instituto Geológico y Minero de España, 71 (1960), 1-346, mapa geol. y cortes.

Knight, J.A. 1983a. The stratigraphy of the Stephanian rocks of the Sabero Coalfield, León (NW. Spain) and an investigation of the fossil flora. Part I. The stratigraphy and general geology of the Sabero Coalfield. Palaeontographica, Abt. B, 187, 1-88.

Knight, J.A. 1983b. The stratigraphy of the Stephanian rocks of the Sabero Coalfield, León (NW. Spain) and an investigation of the fossil flora. Part II. Systematic palaeobotany, introduction, Pteridospermae. Palaeontographica, Abt. B, 187, 155-248.

Kutterink, J.A. 1966. Geologie van het Valdeón-Gebied in Spanje. Doctoraal Scriptie Geologisch Instituut, Rijksuniversiteit Leiden, 28 pp., kaarten en profielen (unpublished degree thesis).

Maas, K. 1974. The geology of Liébana, Cantabrian Mountains, Spain: deposition and deformation in a flysch area. Leidse Geologische Mededelingen, 49, 379-465, geol. map and sections.

Maas, K. and Ginkel, A.C. van. 1983. Variscan olistostrome deposition and synsedimentary nappe emplacement, Valdeón area, Cantabrian Mountains, Spain. Leidse Geologische Mededelingen, 52, 341-381, map and sections.

Martínez-García, E. 1981. El Paleozoico de la Zona Cantábrica Oriental. Trabajos de Geología, 11, 95-127.

Martínez-García, E. 1991. Hercynian syn-orogenic and postorogenic successions in the Cantabrian and Palentian zones (NW Spain). Comparison with other western European occurrences. Giornale di Geologia, 53, 209-220.

Martínez-García, E. y Villa, E. 1986. Una discordancia importante en el Carbonífero de los Picos de Europa (Asturias, NW de España). Actas IX Congreso Nacional de Sedimentología, Salamanca, 1980, Acta Salmanticensia, 50, 719-726.

Martínez-García, E. and Wagner, R.H. 1971. Marine and continental deposits of Stephanian age in eastern 
Asturias (NW. Spain). Trabajos de Geología, 3, 285305.

Martínez-García, E. y Wagner, R.H. 1982. Una cuenca marina del Estefaniense superior en el Noroeste de España. Trabajos de Geología, 12, 119-124.

Martínez-García, E., Rodríguez Arango, R. and Villa, E. 1985. The unconformable marine Kasimovian strata of the Sellaño Basin (Cantabrian Zone, NW Spain). In: Papers on the Carboniferous of the Iberian Peninsula (Eds. M.J. Lemos de Sousa \& R.H. Wagner). Anais da Faculdade de Ciências, Universidade do Porto, Supplement to Volume 64 (1983), 35-40.

Rodríguez-Fernández, L.R. y Heredia, N. 1988. La estratigrafía del Carbonífero y la estructura de la unidad de Pisuerga-Carrión, NO de España. Cuaderno Laboratorio Xeolóxico de Laxe, 12 (1987), 207-229.

Rodríguez-Fernández L.R., Heredia, N., Barba, P., Gallastegui, G., Villa, E. y Leyva, F. 1989. Mapa Geológico de España. Escala 1:50.000: Hoja 54 (Rioseco). Memoria, 108 pp.

Rodríguez-Fernández L.R., Barba, P., Bahamonde, J.R., Heredia, N., Colmenero, J.R., Fernández, L.P., AlonsoHerrero, E., Gallastegui, G., Paniagua, A. y Galán, L. 1990. Mapa Geológico de España. Escala 1:50.000: Hoja 80 (Burón). Memoria, 144 pp.

Rodríguez-Fernández L.R., Barba, P., Fernández, L.P., Colmenero, J.R., Alonso-Herrero, E., Alonso, J.L., Heredia, N., Paniagua, A. y Galán, L. 1991. Mapa Geológico de España. Escala 1:50.000: Hoja 105 (Riaño). Memoria, 182 pp.

Santos, J.A., Navarro, D. y Horvath, V. 1990. La cuenca Estefaniense de Canseco-Salamón (Norte de León, Cordillera Cantábrica). Un ejemplo de abanicos aluviales ligados a una zona de fractura. Boletín Geológico y Minero, 101, 507-525.

Villa, E. 1995. Fusulináceos carboníferos del este de Asturias (N de España). Biostratigraphie du Paléozö̈que, 13, $261 \mathrm{pp}$.

Villa, E. y Martínez-García, E. 1989. El Carbonífero Superior marino de Dobros (Picos de Europa, NW de España) y su contenido en fusulináceos. Trabajos de Geología, 18, 77-93.

Wagner, R.H. 1963. A general account of the Palaeozoic Rocks between the Rivers Porma and Bernesga (León, NW. Spain). Boletín Instituto Geológico y Minero de España, 74, 171-331, geol. map and sections.

Wagner, R.H. 1965. Palaeobotanical Dating of Upper Carboniferous Folding Phases in NW. Spain. Memorias Instituto Geológico y Minero de España, 66, 169 pp.

Wagner, R.H. 1971. The stratigraphy and structure of the Ciñera-Matallana Coalfield (prov. León, N.W. Spain). Trabajos de Geología, 4, 385-429.

Wagner, R.H. 1984. Megafloral Zones of the Carboniferous. Compte Rendu 9 Congrès Carbonifère, Washington and Champaign-Urbana, 1979, 2, 109-134.

Wagner, R.H. \& Sousa, M.J.L. 1982. Systematics and distribution of Linopteris florini TEIXEIRA and Linopteris gangamopteroides (DE STEFANI) WAGNER. Comunicações Serviços Geologicos de Portugal, 68 (2), 247-256.

Wagner, R.H. and Winkler Prins, C.F. 1985. The Cantabrian and Barruelian stratotypes: A summary of basin development and biostratigraphic information. In: Papers on the Carboniferous of the Iberian Peninsula (Eds. M.J. Lemos de Sousa \& R.H. Wagner). Anais da Faculdade de Ciências, Universidade do Porto, Supplement to Volume 64 (1983), 359-410. 